\title{
Households Willingness to Pay for Improved Waste Management In Silchar Municipal Area: A Case Study In Cachar District,
} Assam.

\author{
Ashish Taru Roy ${ }^{1}$ and Uttam Deb ${ }^{2}$ \\ ${ }^{1}$ (Department of Economics, Assam University, India) \\ ${ }^{2}$ (Department of Economics, Assam University, India)
}

\begin{abstract}
This paper investigates the willingness to pay for an improved waste management in Silchar municipal area under Cachar district in Assam. On an average, 63\% of the households are willing to pay for improved waste management. It is therefore apparent that Silchar residents in general regard waste management as an environmental service as they are willing to pay for its provision. An open ended contingent valuation method was used to elicit households' willingness to pay for waste management. We used a multiple regression model to establish the determinants of willingness to pay. The multiple regression estimates revealed that those with a higher expenditure (proxy of income) are willing to pay for an improved waste management. This finding corroborates the environmental economic theory which assumes that the demand for an improved environmental quality increases with income. More aware the person the more they are willing to pay for improved waste management. Larger families are willing to pay for an improved provision of waste management services. Also, educated people are more willing to pay for improvement. Also the presence of working woman in the family does influence the willingness to pay.
\end{abstract}

Keywords: Contingent Valuation Method, Environmental service, Multiple regression model, Waste management, Willingness to Pay.

\section{Introduction}

The purpose of this paper is to determine whether household in Silchar, Cachar are willing to pay for improved waste collection and disposal facility. The survey is in the quest of finding out the monetary value that households are able and willing to attach for an improved waste management service. The study determines the coping mechanisms adopted by households in Silchar to alleviate the impacts of unreliable waste collection and poor or unsafe disposal facility, and the related costs incurred.

Efficient waste management is vital for health and improvement of the well being of human beings. If the ongoing waste management by municipality does not offer efficient waste collection and disposal facility continuously, concerned and private agents might interfere. Therefore, this paper brings in the required information on the willingness of households of Silchar, Cachar, for an improved and sustained service provision.

Silchar, as a historical centre and the District headquarter is the centre of many social and economic activities. This has led to the rapid population increase (Table 1 below), increased consumption resulting increased in waste and the cost of clearing waste. Therefore, there is need to investigate factors influencing the households' willingness to pay (WTP) for improved waste management services, such as collection and disposal.

Table 1: Population Growth in Silchar between 1951 and 2011

\begin{tabular}{|l|l|l|l|l|l|l|}
\hline 1951 & 1991 & 2001 & 2011 \\
\hline Population & Population & $\begin{array}{l}\text { Annual } \\
\text { growth rate }\end{array}$ & Population & $\begin{array}{l}\text { Annual } \\
\text { growth rate }\end{array}$ & Population & $\begin{array}{l}\text { Annual } \\
\text { growth rate }\end{array}$ \\
\hline 34000 & 115483 & $6.0 \%$ & 142199 & $2.3 \%$ & 172710 & $2.1 \%$ \\
\hline
\end{tabular}

Source: Office of the Registrar General and Census Commissioner (web), Population Census India (web).

There is a concern that waste management in Silchar is of poor quality and collection of garbage is irregular. Preliminary investigations have revealed that environmentally unlawful and improper disposal of waste by residents can potentially be the cause of the following range of health hazards: 1) inhalation of contaminated dust, toxins and smoke from burning waste, 2) breeding of vectors that spread disease, 3) pollution of surface and groundwater, 4) infection from contaminated wastes, especially if they are reused, 5) poisoning and injury by hazardous chemicals. Any satisfactory method of waste disposal must prevent or dramatically reduce the probability of all these threats. 
Furthermore, as a result of poor waste management and irregularity of its collection, residents in some parts of Silchar adopt in what refers to as 'informal waste disposal arrangement'. This is the household's expenditure related to reducing health risks from environmental pollution by private arrangement of disposing waste through 'thelawala'- a person who collects the waste of a lane by hand-driven uncovered containerized cart or other small vehicle in lieu of payment. This implies that the residents incur the personal waste disposal costs along with the cost of municipal tax. This necessitates the improvement of current waste management system in the city. The foregoing raises the following question to be answered by this investigation. Are residents of Silchar, willing to pay in order to increase efficiency, regularity and improved waste collection and disposal system especially house-to-house collection system?

The paper is organized as follows: Section 2 summarizes the waste management scenario in Silchar; Section 3 highlights economic valuation of an environmental service; Section 4 provides an overview of previous studies. Methodological procedures are discussed in Section 5. Empirical findings are presented in Section 6, while concluding remarks are given in the last section.

\section{Waste Management Scenario in Silchar}

It is necessary to know where we are before we can plan the route to the place where we wish to be. The present scenario of waste management in Silchar is characterized by following state of affairs: 1) streets are generally treated as the receptacles of waste. Consequently, unsanitary conditions affect overall health and environment, 2) there is hardly any segregation of recyclable waste. Waste paper, plastic, metal, glass, rubber, rags and so on are thrown on the streets along with domestic, trade and institutional wastes, 3) transportation is not well coordinated with primary collection, resulting in multiple and manual handling of waste. This is injurious to the health of waste disposal workers, 4) waste collection from waste disposal sites (by collection vehicles) is irregular and hence leads to over accumulation. This is injurious to the health of all passersby, 5) the method of crude dumping is adopted for waste disposal. Waste is not spread, compacted or covered. In order to achieve the ideal situation, there should be a marked improvement in the entire waste disposal chain relative to the situation. At present, the situation is not at par with compliance criteria laid down in Municipal Solid Wastes (Management and Handling) Rules 2000.

Table 2: Implementation Schedule (Schedule I)

\begin{tabular}{|l|l|l|}
\hline Serial No. & Compliance Criteria & Schedule \\
\hline $\mathbf{1}$ & Setting up of waste processing and disposal facilities & By 31.12.2003 or earlier \\
\hline $\mathbf{2}$ & $\begin{array}{l}\text { Monitoring the performance of waste processing and } \\
\text { disposal facilities }\end{array}$ & Once in six months \\
\hline $\mathbf{3}$ & $\begin{array}{l}\text { Improvement of existing landfill sites as per provision } \\
\text { of these rules }\end{array}$ & By 31.12.2001 or earlier \\
\hline $\mathbf{4}$ & $\begin{array}{l}\text { Identification of landfill sites for future use and } \\
\text { making site(s) ready for operation }\end{array}$ & By 31.12.2002 or earlier \\
\hline
\end{tabular}

Source: Municipal Solid Wastes (Management and Handling) Rules, 2000.

It has been clearly mentioned in the Management of Municipal Solid wastes Schedule-II that littering of municipal solid waste shall be prohibited in cities, towns and in urban areas notified by the State Governments. As according to Schedule III, to prohibit littering and facilitate compliance the following steps shall be taken by the municipal authority in the case of waste collection from households:-

(i) Organising house-to house collection of municipal solid wastes through any of the methods, like community bin collection (central bin), house-to-house collection, collection on regular pre-informed timings and scheduling by using bell ringing of musical vehicle (without exceeding permissible noise levels);

(ii) Collected waste from residential and other areas shall be transferred to community bin hand-driven containerized carts or other small vehicles.

(iii) The municipal authority shall notify waste collection schedule and the likely method to be adopted for public benefit in a city or town.

(iv) It shall be the responsibility of generator of wastes to avoid littering and ensure delivery of wastes in accordance with the collection and segregation system to be notified by the municipal authority.

The local municipal authority has only succeeded to notify the likely method to be adopted for public benefit in the town. Due to lack of house-to-house waste collection and appropriate community bins in the residential areas, littering continues to be a problem. Private treatment of waste disposal through 'thelawala' does not encourage segregation system as people throw both biodegradable and non-biodegradable objects in the thela. Final disposal of these wastes is also not environmentally hygienic as most of the 'thelawala' throw garbage in the vacant lands inside the town. There is complete absence on the part of the municipal authority to organize awareness programme for segregation of wastes and promoting recycling or reuse of segregated 
materials and also the regular meetings at quarterly intervals with representatives of local resident welfare associations and non-governmental organizations. At this situation, 'Para'or lane committee or lane development committee initiates and ensures private handling of waste collection and disposal system in most of the wards in the town. Currently local municipality collects garbage from some selected spots in the town by medium size trucks and dumps it to the 'Meherpur' trenching ground, $2.5 \mathrm{KM}$ away from the city.

\section{Economic Valuations of Environmental Service}

Economic Valuation is about "measuring the preferences" of people for an environmental good or against an environmental bad. The economic value of something is measured by a summation of many individuals` willingness to pay (WTP) for it. The WTP reflects individuals preferences for the good in question. Valuation is in money terms because of the way in which preference revelation is sought. i.e., by asking people how much they are willing to pay. Many of environmental goods and services are provided freely. Therefore, they have zero prices because no market place exists in which their true values can be revealed through acts of buying and selling. Projects and programmes appraisal cannot be sufficient or adequate without valuation. National priorities for environmental policies are better informed if economic values are known with a degree of certainty (Pearce, 1993) [1]. Economic valuation of environmental goods has found vast application in determining compensatory payments for environmental damage (Willis and Corkindale, 1995) [2]. Valuation techniques are also applied to the more immediate human environment, such as water supply, waste management and sanitation. This paper employs the Contingent Valuation Method (CVM) to determine the willingness to pay for improved waste collection and disposal system in Silchar. The CVM is a survey-based technique of monetary valuation used to elicit people's preferences expressed in terms of WTP. The CVM utilizes an appropriately designed questionnaire (or experiment) to elicit the valuations or bids of households about a decrease or increase in the amount of an environmental good, and how much they are willing to pay or to accept compensation in order to avoid an environmental damage. The assumption is that a market for environmental goods and services exist (Pearce and Turner, 1990) [3]. It makes use of bidding games for approximating the willingness of households to pay for an environmental service. The CVM can be carried out by several ways such as the use of (1) direct questionnaires, (2) face-to-face interviews, (3) mail surveys, and (4) telephone. Single bid games, also known as the single open-ended, is used in this study. This is where the respondent is asked to mention the amount he or she is willing to pay for a service described by the interviewee. A CV study needs three basic things. First, the respondent should be given detailed information about the service to be valued and the hypothetical scenario under which it is made available. For example, the structure under which the service is provided, the range of available substitutes and the method of payment. Second, a method which elicits respondent's willingness to pay (WTP) is required. The respondents are asked for their maximum WTP (e.g., per month). Third, demographic information (such as age, gender, income, education) is needed to estimate the valuation function for the environmental service. The data obtained are used in regression analysis to estimate how the values are related to the respective demographic variables based on theory.

A CVM exercise basically involves informing the respondent about the prevailing situation (prices, environmental conditions, etc), and then informs him/her about a change. The individual is asked to value a particular change in environmental conditions in a future hypothetical scenario. Contingent Valuation evolved as a method to quantify the benefits of non-market environmental goods and attributes in order to allow them to be entered directly into cost-benefit calculations. CVM have the advantages over the other methods of environmental valuation such as the travel-cost and hedonic pricing techniques. The method is able to quantify some types of benefits, such as non-use or passive use benefits, which lie outside the scope of travel-cost and hedonic pricing studies. CVM is able to measure passive use values and this has led to many applied environmental economists choosing it (Hanemann, 1991) [4].

However, critics of CVM are critical of the reliability and validity of answers to hypothetical WTP questions. They argue that the method is prone to a number of difficulties (or biases). First, there is always the possibility of strategic behavior. Respondents may understate their willingness to pay if they feel that they can free-ride or they may overstate their willingness to pay. This can arise if they feel that the provision of the superior situation is not conditional on their actual payments. Therefore, a careful design of the questionnaire and description of the service is needed to minimize this kind of bias. Second, the respondents may answer only to please the interviewer. Third, there exist the hypothetical nature of the process calling for careful structuring of questions to inform respondents about the relevant points, and not overloading them with unnecessary description. It is therefore argued that precise assessments of the environmental change need appropriate information provision. Fourth, a range of other problems that are coupled with contingent valuation incorporate responses bias and starting point biases (Mitchell and Carson (1989) [5]. Moreover, the cross-sectional Contingent valuation studies have tended to have low R-squared, though; R-squared is used to demonstrate that WTP amounts are not random responses. Mitchell and Carson have indicated that the reliability of a CV study which fails to show an $\mathrm{R}^{2}$ of at least 0.15 , using only a few key variables, is open to question. These biases are a 
result of difficulties for households in perceiving the hypothetical or contingent market or from choice of starting point of bids (Pearce and Turner; 1990 [6], Jimson, 2001 [7]). Even with all these biases, accurate estimates of WTP can be made. Generally, the CVM has found vast applications in case of developing countries. It has surpassed other environmental resources valuation techniques. Contingent Valuation can specifically estimate WTP for an environmental good or service.

\section{Review of Previous Studies.}

Most empirical studies on the WTP for improved waste collection and disposal system indicate that age, household size, sex, marital status, education and household expenditure influence willingness to pay for improved waste management. For instance, Niringiye and Omortor (2010) [8] found that age of the respondents has a negative and significant effect on WTP for waste management in Kampala city in Uganda. In 2007, Yusuf, Salimonu and Ojo [9] did a study on WTP for improved household solid waste management in Oyo State, Nigeria. The study results showed that the mean willingness to pay of households for improved solid waste management is N1240.92. The results further revealed that the significant factors determining households' willingness to pay for improved solid waste management (collection and disposal) are the posted price of the service, age, educational level, household size and household's monthly expenditure. In a study of municipal solid waste management of Tinsukia Municipality of Assam in India, Das and Gogoi (2010) [10] observed that Cost Sharing of waste management is affected by family income positively. They found that if the family income increases then the probability that the people are in favor of cost sharing is $13 \%$. The study further revealed that the amount of monthly waste generated per household has also influence on peoples WTP for waste management. The authors found that if the amount of garbage generated increase by $1 \mathrm{~kg}$ per month then the chances that the people are in favor of cost sharing is $21 \%$. The studies reviewed above have all employed CVM to solicit WTP for improved waste management services.

\section{Methodology}

In this section we focus on data collection, methodological procedures and sampling strategy. Two methods of Data collection were used to collect household data in the study area. These are household questionnaire and key informant interviews.

\subsection{The Questionnaire}

A questionnaire with open-ended questions was administered to households. The questionnaire consisted of the following five sections: i) introduction, household location, ii) socio-economic information, iii) households' attitude regarding waste disposal practices, iv) households' awareness and opinion regarding solid waste management, v) willingness to pay for improved waste management. Section five is basically Contingent Valuation question. The questions were designed to get the most precise data for econometric analysis of willingness of pay. Interviews were conducted with the head of the household. Vacant households were replaced by next one in the list. After entering and cleaning data, the data was ready for analysis. For individuals who were sharing, that was treated as two households. The interviews lasted 15-30 minutes.

\subsection{Key informant interviews}

Chairperson and Head Clerk from the local municipality and any other relevant authority that was resourceful were also interviewed in order to get some more information on the ground. For instance, the chairperson gave information on status of waste collection and disposal system.

\subsection{Sampling strategy}

Silchar Municipal Area, an area with a high concentration of the working population was purposively selected. It was thought that Contingent Valuation would be appropriate to apply in this area, as the population is relatively more educated. This is mainly because Contingent Valuation works effectively if it is applied to a more educated and informed population. Silchar Municipality has 28 wards under it. All households under these wards were listed, and a total of 19563 households were estimated. Of the total number of households, 2 percent of households from each ward was selected the total of which is approximately 378 households for an interview using systematic sampling. The systematic sampling technique was used whereby every $5^{\text {th }}$ building in the area was sampled. The study would have benefitted from higher sample size but due to inadequate funding the sample size could not be increased.

\subsection{Model Specification}

The specification of the equation below was primarily motivated by theory and relevant literature. In the model, WTP is endogenously determined and is a function of the following independent variables monthly 
average household expenditure, household size, average education, environmental awareness, number of working woman and informal waste disposal arrangement.

Thus: $\mathrm{WTP}=\beta 0+\beta 1 \mathrm{MAHE}+\beta 2 \mathrm{HSZ}+\beta 3 \mathrm{AE}+\beta 4 \mathrm{AW}+\beta 5 \mathrm{NWW}+\beta 6 \mathrm{IWDA}+\varepsilon(1)$

Where; $\beta 1>0, \beta 2<0, \beta 3>0, \beta 4>0, \beta 5>0, \beta 6>0$

Where,

WTP: Maximum willingness of Silchar residents to pay for improved waste management (in monetary terms, Rupee)

$\beta 0$ : Constant

$\beta i$ : Coefficients where $\mathrm{i}=1$ to 6

MAHE: Monthly average household expenditure

HSZ: Household size

AE: Average education of the family which is total years of schooling of the family members divided by the total member of family.

AW: Environmental awareness which is total number of desirable responses divided by total number of awareness questions multiplied by 100 .

NWW: Number of working woman in the family.

IWDA: Informal waste disposal arrangement where IWDA $=1$ for having the arrangement and IWDA= 0 for not having the arrangement.

\section{$\varepsilon$ : Error Term.}

\subsubsection{Priori Expectations}

MAHE; Expenditure is expected to be positively related to WTP. Monthly average household expenditure enters the model as a proxy of income. Environmental economic theory assumes that the demand for an improved environmental quality increases with income. Consequently, those with a higher income are expected to be more willing to pay for an improved waste management.

HSZ; Household size is expected to be inversely related to WTP. It is assumed that big households will be willing to pay relatively less due to the associated high running costs (i.e. budgetary constraints). Thus, the study expects the sign of its coefficient to be negative.

AE; WTP for improved waste is expected to be positively related to education. The longer time in formal schooling (years), the more people understand better the consequences of using unsafe waste collection and disposal method. Therefore, the educated will be more willing to pay than the illiterate.

AW; It is hypothesized that the higher the level of environmental awareness the more the respondent would appreciate the consequence of mishandling solid waste and more value the individual would give in order to avoid the risk of being a victim of unclean environment.

NWW; Number of working woman is supposed to affect WTP. A positive relationship between WTP and NWW might exist because working women are the ones who take care of domestic household everyday jobs and travelling to other places, hence their presence will influence willing to pay.

IWDA; Informal waste disposal arrangement refers to undertaking personal waste treatment measures such as hiring the 'thelawala', giving him the charge of disposing waste. The study expects a positive relationship between the variable WTP. Households will be willing to pay since they incur so many costs including paying the urban tax and yet the scenario is not environmentally hygienic.

\section{Empirical Findings and Analysis of Data}

This section is divided into descriptive analysis and regression results. The findings of this study are based on the sample data collected from 28 wards in Silchar. Three hundred and seventy eight (378) households were covered out of a total of 19563 (Silchar Municipal Board, 2010) households in 28 wards. This means that the survey covered only 2 percent of the households in each ward. The results of this study show that on average, 63 percent of the households in Silchar are willing to pay for improved waste management. Despite the smallest of the sample relative to population size and for the sake of argument, assuming that the sample is nevertheless representative, it means that 12324 households in Silchar are willing to pay for improved waste management. Consequently, if all households in Silchar who are willing to pay are going to be charged rupees Rs 127.47 per month, Rs $1570940(12324 *$ Rs 127.47) will be collected from such a service.

\subsection{Descriptive Analysis}

This sub-section is composed of some descriptive statistics on method of waste disposal adopted by the household and the satisfaction level of household regarding municipal activities. 


\subsubsection{Method of waste disposal adopted by the household}

The study reveals the poor environmental quality and pollution hazard of the area. It is evident that a negligible percentage of the household respondent that they do not observe people throwing waste in the drain while major share of the household (73\%) responded that they notice people throwing waste in drains and roadside. These improperly duped wastes are breeding grounds of insects, pests and infectious diseases and also produce toxic gases, which spread odor around the dumping places. The study indicates that a majority of people do not have access to proper waste disposal facilities. The following Fig. 6.1.1 depicts the picture of the waste disposal method followed by the household of Silchar municipal area.

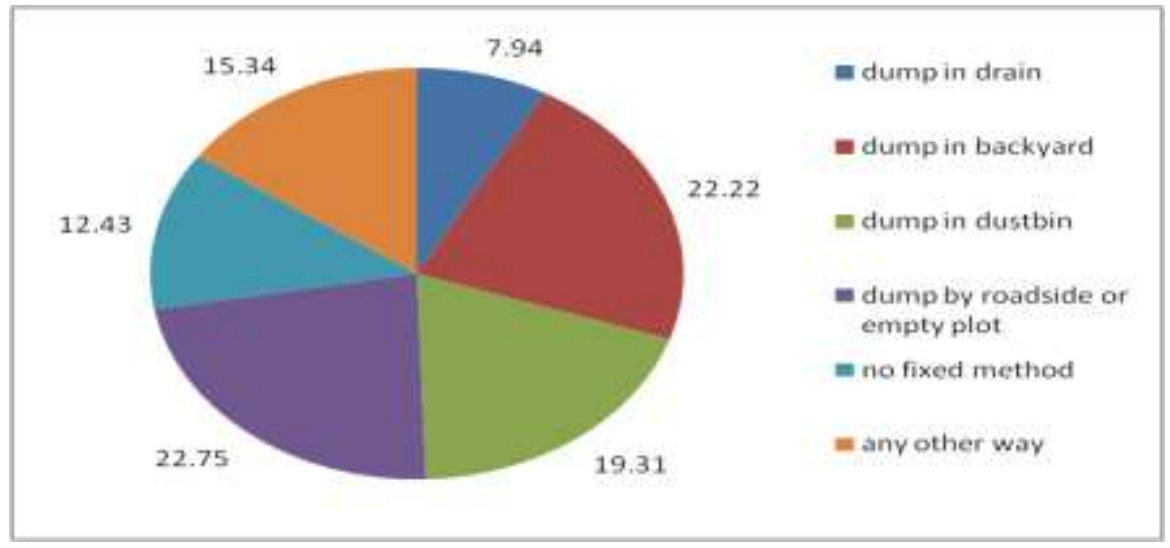

Figure 6.1.1: Household waste disposal method

\subsubsection{Satisfaction level of the household regarding municipal activities}

The cleanliness of environment of an area depends on the regularity in the collection of waste by the municipality. The response of the household regarding the frequency of waste collection by the municipality is not satisfactory because a major percentage of household answered that the collection of waste is not regular.

Table 3: Satisfaction Level of the Household

\begin{tabular}{|l|l|}
\hline Frequency of waste collection & Opinion (\%) \\
\hline Regularly once a week & 11.64 \\
\hline More than once week & 5.56 \\
\hline No regular system & 36.77 \\
\hline Do not collect & 39.68 \\
\hline No idea & 6.35 \\
\hline
\end{tabular}

Source: primary survey, 2012

The satisfaction level of the respondent household with regard to the waste collection service as provided by the municipal board illustrates that $75 \%$ of the surveyed household are not satisfied with the collection service of the municipality. They think that the municipality has completely failed in proper waste management. $16 \%$ of the respondents are satisfied with the services of the municipality. They are of the view that during the last 2-3 years the municipality has improved a lot in their services compared to past but it is still not sufficient.

Regarding the steps taken when the clearance of waste is not regular, some household inform the municipality, some of them meets the ward commissioner. Majority household try to manage it themselves by making private arrangements while there are also some household which do not take any steps in this regard.

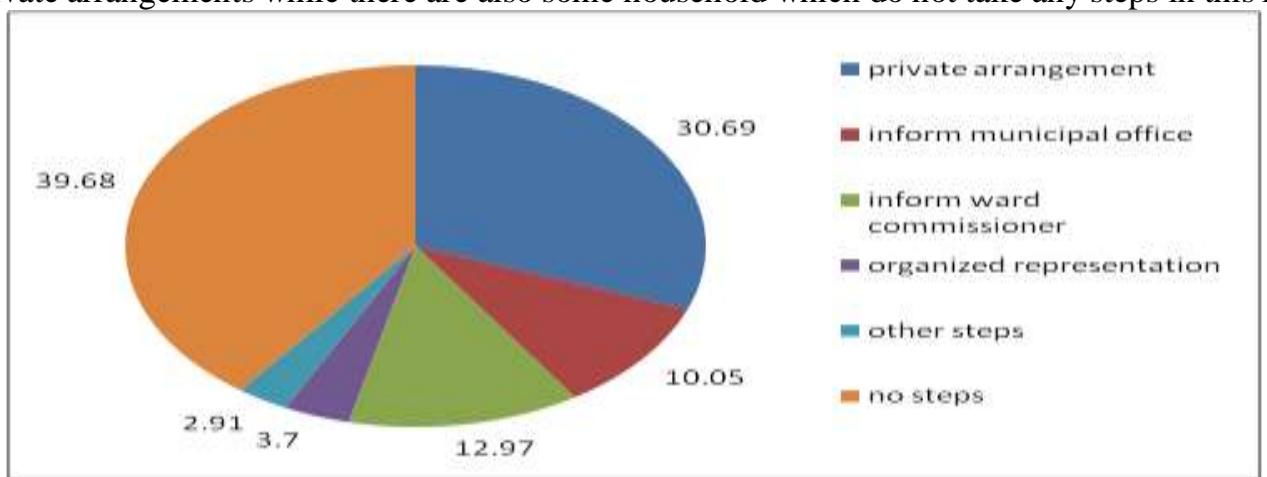

Figure 6.1.2: Steps taken when the clearance of waste is not regular (in \%) 
Since waste management service is provided by the local municipal authority there was substantial evidence to suggest that the waste management affairs left much to be desired. The issue of irregular clearance of garbage does affect the continuity of the waste management service. This means breakdowns here and there are really an order of the day. This implies that vast pressure is exerted on the available resources to keep up with the prevailing situation. The local authority spends a lot of money through maintaining and installing garbage compactor, tripper, truck and laborers.

About sixty-three percent $(63.2 \%)$ of the households believed that the establishment of a fund to improved the waste management was necessary. The average maximum WTP for improved waste management was Rs 127.47. The remaining 36.8 percent did express reservations because they regarded waste management as an entitlement to them that should be provided by the government. This can be attributed to the fact that people are getting waste management as a social service from government. However, due to the problem of sustainability of services, it is vital that people view waste management as an environmental service.

\subsection{Regression Results}

The Willingness to pay equation was estimated using SPSS Version 15.0 to determine the relationship between WTP and each of the variables as earlier discussed. To estimate the maximum level of WTP for waste management in Silchar, only those households are considered those who want to contribute some amount. It is found that 239 (around 63 percent) of the households want to pay some amount for the improved betterment purposes and for this reason only these households are taken as observations in this analysis.

Table 4: Descriptive Statistics on WTP for Improved Waste Management

\begin{tabular}{|l|l|l|l|l|l|l|}
\hline Dependent variables & $\mathrm{N}$ & Mean & Maximum & Minimum & $\begin{array}{l}\text { Std. } \\
\text { deviati } \\
\text { on }\end{array}$ & $\begin{array}{l}\text { Coff. Of } \\
\text { variation }\end{array}$ \\
\hline $\begin{array}{l}\text { Maximum amount household } \\
\text { are willing to contribute for } \\
\text { improved waste management }\end{array}$ & 239 & 127.47 & 350 & 10 & 63.85 & .501 \\
\hline
\end{tabular}

Source: primary survey, 2012

Table 5: Descriptive Statistics in Relation to the Variables

\begin{tabular}{|c|c|c|c|c|c|c|}
\hline Variable & $\mathrm{N}$ & Mean & Maximum & Minimum & $\begin{array}{l}\text { Std. } \\
\text { deviation }\end{array}$ & $\begin{array}{l}\text { Coff. Of } \\
\text { variation }\end{array}$ \\
\hline $\begin{array}{l}\text { Monthly } \\
\text { average } \\
\text { household } \\
\text { expenditure }\end{array}$ & 239 & 4348.43 & 25000 & 375 & 2767.96 & .637 \\
\hline $\begin{array}{l}\text { Household } \\
\text { size }\end{array}$ & 239 & 4.01 & 11 & 1 & 1.54 & 0.384 \\
\hline $\begin{array}{l}\text { Average } \\
\text { education }\end{array}$ & 239 & 13.07 & 19 & 7 & 2.05 & 0.157 \\
\hline $\begin{array}{l}\text { Environmental } \\
\text { Awareness }\end{array}$ & 239 & 69.11 & 100 & 30 & 12.09 & 0.175 \\
\hline $\begin{array}{l}\text { Number of } \\
\text { working } \\
\text { woman }\end{array}$ & 239 & 0.34 & 4 & 0 & 0.543 & 1.6 \\
\hline $\begin{array}{l}\text { Informal } \\
\text { waste disposal } \\
\text { arrangement }\end{array}$ & 239 & 0.380 & 1 & 0 & 0.477 & 1.3 \\
\hline
\end{tabular}

Source: primary survey, 2012

Table 6: Results of the Regression Analysis to the WTP Model

\begin{tabular}{|l|l|l|l|l|}
\hline Variable & Coefficient & Std. error & t-statistic & p-value \\
\hline Constant & -49.490 & 25.790 & $-1.925^{*}$ & 0.055 \\
\hline MAHE & 0.004 & 0.001 & $3.581^{* * *}$ & 0.000 \\
\hline HSZ & 7.759 & 2.140 & $3.625 * * *$ & 0.000 \\
\hline AE & 5.898 & 1.587 & $3.716^{* * *}$ & 0.000 \\
\hline AW & 0.578 & 0.258 & $2.978 * * *$ & 0.003 \\
\hline NWW & 16.988 & 5.705 & $2.978^{* * *}$ & 0.003 \\
\hline
\end{tabular}




\begin{tabular}{|l|l|l|l|l|}
\hline IWDA & 9.204 & 6.431 & 1.431 & 0.153 \\
\hline $\mathrm{R}^{2}=0.359$ & \multicolumn{4}{|c|}{ Adjusted $\mathrm{R}^{2}=0.348$} \\
F-stat=12.100*** & No. of observations $=239$ \\
DW-Statistic= 1.926 & & & \\
\hline
\end{tabular}

Source: primary survey, 2012

*** Statistically Significant at $1 \%$ level, * Statistically Significant at $10 \%$ level

The coefficient of determination of the model shows that 35.9 percent of variations in WTP are attributed to the explanatory variables and the remaining 64.1 percent is unexplained. The $\mathrm{R}^{2}$ value for the regression model is 0.359 and it is considered quite acceptable, because Mitchell and Carson (1989) [11] and O'Garra (2009) [12] mentioned that regressions on CV data usually yield $\mathrm{R}^{2}$ values between $10 \%$ and $40 \%$. In Table 9, all the estimated coefficients had expected signs except household size (HSZ). Furthermore, IWDA was found to be statistically insignificant, implying that it does not affect WTP.

Monthly average household expenditure (MAHE) has the expected positive sign and is statistically significant at 1 percent. This implies that with increased monthly expenditure, the household WTP will increase. From Table 9, estimation coefficient of expenditure suggests that a unit increase in household expenditure will result in Rs 0.004 increase in WTP.

Household size (HSZ) significant at 1 percent but does not have the expected negative sign. The estimation coefficient of household size implies that a unit increase in household size will increase WTP by Rs 7.759. This suggests that the bigger the family size more will be the volume of waste and the more difficulties encountered in terms of waste disposal in the urban area, hence the increased WTP.

Average Education (AE) has an expected positive sign and it is the most significant variable at 1 percent level. This means that the higher the number of years for schooling, the more the WTP. The slope coefficient of education can thus be interpreted as follows, holding everything else constant; a one-year increase in education level will increase WTP by Rs 5.898. This might be attributed to the fact that higher level of education enhances consciousness among the people.

Environmental awareness (AW) is significant at 1 percent and has the expected positive sign. The variable awareness affects WTP for improved waste management. This suggest that the more aware the person the more he/she willing to pay for improved waste management. This was evident since most respondents' for contributing was for the clean and safe environment. The coefficient of age can be interpreted as follows, holding everything else constant; a percentage increase in the respondent's awareness will increase by Rs 0.578 .

Number of working woman (NWW) variable is also significant at 1 percent and has the expected positive sign. This suggests that the number and presence of working woman in the family does affect the WTP for improved waste management. As working woman is to deal in household affair along with their professional life, it would therefore be convenience for them if house-to house to collection of waste is introduced.

Informal waste disposal arrangement (IWDA), a dummy variable, is statistically insignificant. According to this model, the variable does not explain WTP. This might be attribute to the fact that most household interviewed having IWDA were not wiling not pay, therefore, they were no distinct variations in the dummy to effectively depict the significant of the variable.

\section{Conclusion}

This paper examined the WTP for an improved waste management in Silchar municipal area in Cachar district. Owing to degrading environmental quality and lack of initiatives by the municipality, the households are willing to share cost for waste management services. They are also ready to pay for the clearance of garbage on volumetric basis. Most of the household suggested that proper government intervention will help in better management of waste. It is found that most of the household waste is covered by biodegradable wastes and other consists of plastic, paper, metals and others. Composting of biodegradable wastes and increased waste recycling and recovery are identified as areas for further development. It must be a positive sign for municipality to make proper use of the biodegradable waste. But it is found that no such steps are taken by the municipality till date. Thus the waste management practices of the households and the municipality for cleaning up the residential area is not up to the satisfactory level. It can be concluded that since the environmental quality in the town is not impressive, in demand for a clean and safe environment the households are willing to share cost as well as willing to pay absolute amount of money.

\section{References}

[1] Pearce, D., Economic values and the natural world (Earthscan Publications Ltd, London, 1993).

[2] Willis, K.G., and Corkindale, J.T., Environment valuation, new perspectives (CAB International, Oxon, 1995).

[3] Pearce, D.W., and Turner, R.K., Economics of natural resources and environment (Harvester Wheatsheaf, London, 1990).

[4] Hanemann, W.M., Willingness to pay and willingness to accept: how much can they differ? American Economic Review, 81(3), $1991,635-647$. 
[5] Mitchell, R. and Carson, R., Using surveys to value public goods: the contingent valuation method, (John Hopkins Press, Baltimore, 1989).

[6] Pearce, D.W., and Turner, R.K., Economics of natural resources and environment (Harvester Wheatsheaf, London, 1990)

[7] Jimson, L.S, Valuation of solid waste removal services in northern Lesotho: contingent valuation approach, Unpublished, M.A. Dissertation, Dept. of Economics, University of Botswana, 2001.

[8] Niringiye, A. and Douglas, O.G., Determinants of willingness to pay for solid waste management in Kampala city, Current Research Journal of Economic Theory, 2(3), 2010, 119-122.

[9] Yusuf, S.A., K.K. Salimonu and O.T.Ojo, Determinants of willingness to pay for improved household solid waste management in Oyo state, Nigeria, Research Journal of Applied Sciences, 2(3), 2007, 233-239.

[10] Das, S. and K. Gogoi , Municipal solid waste management in India: a study of Tinsukia municipality of Assam in India, (VDM Verlag Dr. Muller Gmbh \& Co. KG, Germany, 2010).

[11] Mitchell, R. and Carson, R., Using surveys to value public goods: the contingent valuation method, (John Hopkins Press, Baltimore, 1989)

[12] O'Garra, T., Bequest values for marine resources: how important for indigenous communities in less-developed economics? Environmental Resource Economics, 44, 2009, 179-202.

Appendix 1

Correlation Coefficient Matrix for WTP

\begin{tabular}{|c|c|c|c|c|c|c|c|}
\hline & $\begin{array}{l}\text { Maximum } \\
\text { WTP }\end{array}$ & MAHE & HSZ & $\mathbf{A E}$ & $\mathbf{A W}$ & NWW \\
\hline \multirow[t]{2}{*}{$\begin{array}{l}\text { Maximum } \\
\text { WTP }\end{array}$} & $\begin{array}{l}\text { Pearson } \\
\text { Correlation }\end{array}$ & 1 & & & & & \\
\hline & Sig.(2-tailed) & & & & & & \\
\hline \multirow[t]{2}{*}{ МАНЕ } & $\begin{array}{l}\text { Pearson } \\
\text { Correlation }\end{array}$ & $0.192(* *)$ & 1 & & & & \\
\hline & Sig.(2-tailed) & 0.000 & & & & & \\
\hline \multirow[t]{2}{*}{ HSZ } & $\begin{array}{l}\text { Pearson } \\
\text { Correlation }\end{array}$ & $0.106(*)$ & - $0.361(* *)$ & 1 & & & \\
\hline & Sig.(2-tailed) & 0.039 & 0.000 & & & & \\
\hline \multirow[t]{2}{*}{$\mathbf{A E}$} & $\begin{array}{l}\text { Pearson } \\
\text { Correlation }\end{array}$ & $0.273(* *)$ & $0.271(* *)$ & $0.138(* *)$ & 1 & & \\
\hline & Sig.(2-tailed & 0.000 & 0.000 & 0.007 & & & \\
\hline \multirow[t]{2}{*}{$\overline{A W}$} & $\begin{array}{l}\text { Pearson } \\
\text { Correlation }\end{array}$ & $0.183(* *)$ & $0.115(*)$ & 0.064 & $0.190(* *)$ & 1 & \\
\hline & Sig.(2-tailed & 0.000 & 0.026 & 0.216 & 0.000 & & \\
\hline \multirow[t]{2}{*}{ NWW } & $\begin{array}{l}\text { Pearson } \\
\text { Correlation }\end{array}$ & $0.194(* *)$ & -0.004 & 0.097 & $0.188(* *)$ & 0.036 & 1 \\
\hline & Sig.(2-tailed & 0.000 & 0.933 & 0.059 & 0.000 & 0.485 & \\
\hline
\end{tabular}

** Correlation is significant at the 0.01 level (2-tailed).

* Correlation is significant at the 0.05 level (2-tailed).

Source: Authors' calculation based on selected sample in Silchar.

A Brief Acquaintance of Silchar Town:

\section{Appendix 2}

Silchar is the headquarters of Cachar district in the state of Assam in India. It is the economic gateway to the state of Mizoram and part of Manipur. It is 343 kilometers (213 miles) south east of Guwahati and on the left bank of river Barak in 24.82 $\mathrm{N}$ and $92.8^{`} \mathrm{E}$. The city of Silchar is the second largest city of Assam after Guwahati in terms of population and municipal area. The town of Silchar has tremendous commercial importance. It consequently witnesses the settlement of a sizeable population of traders from distant parts of India. It is trade and processing centre for tea, rice and other agricultural products. The city has an airport and lies on both a rail head and national highways connecting Guwahati, Assam; Agartala, Tripura; Imphal, Manipur; and Aizawl in Mizoram state. The area of Silchar town is $15.75 \mathrm{~km}^{2}$. 


\section{Appendix 3}

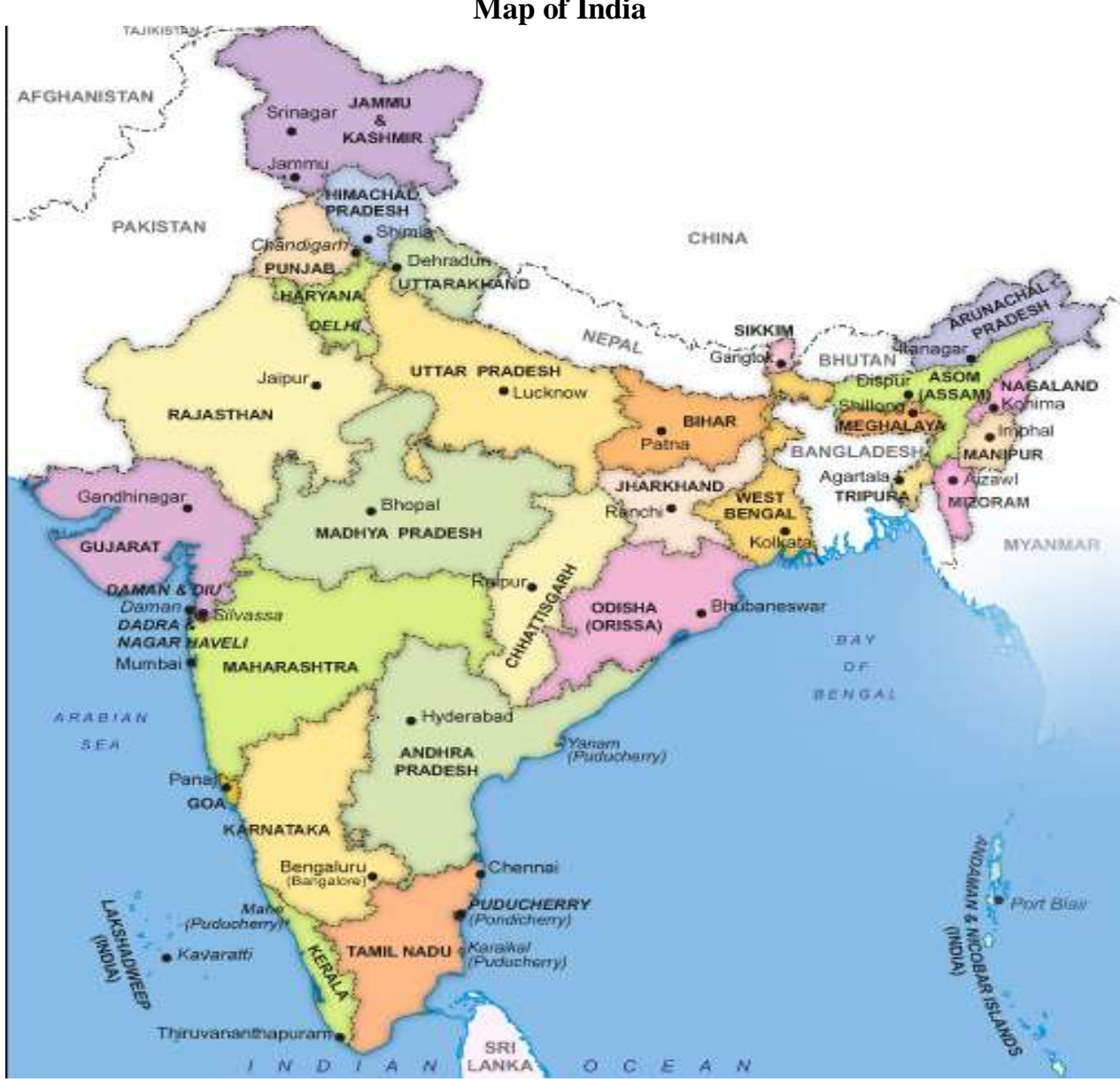

APPENDIX 4

Map of Assam

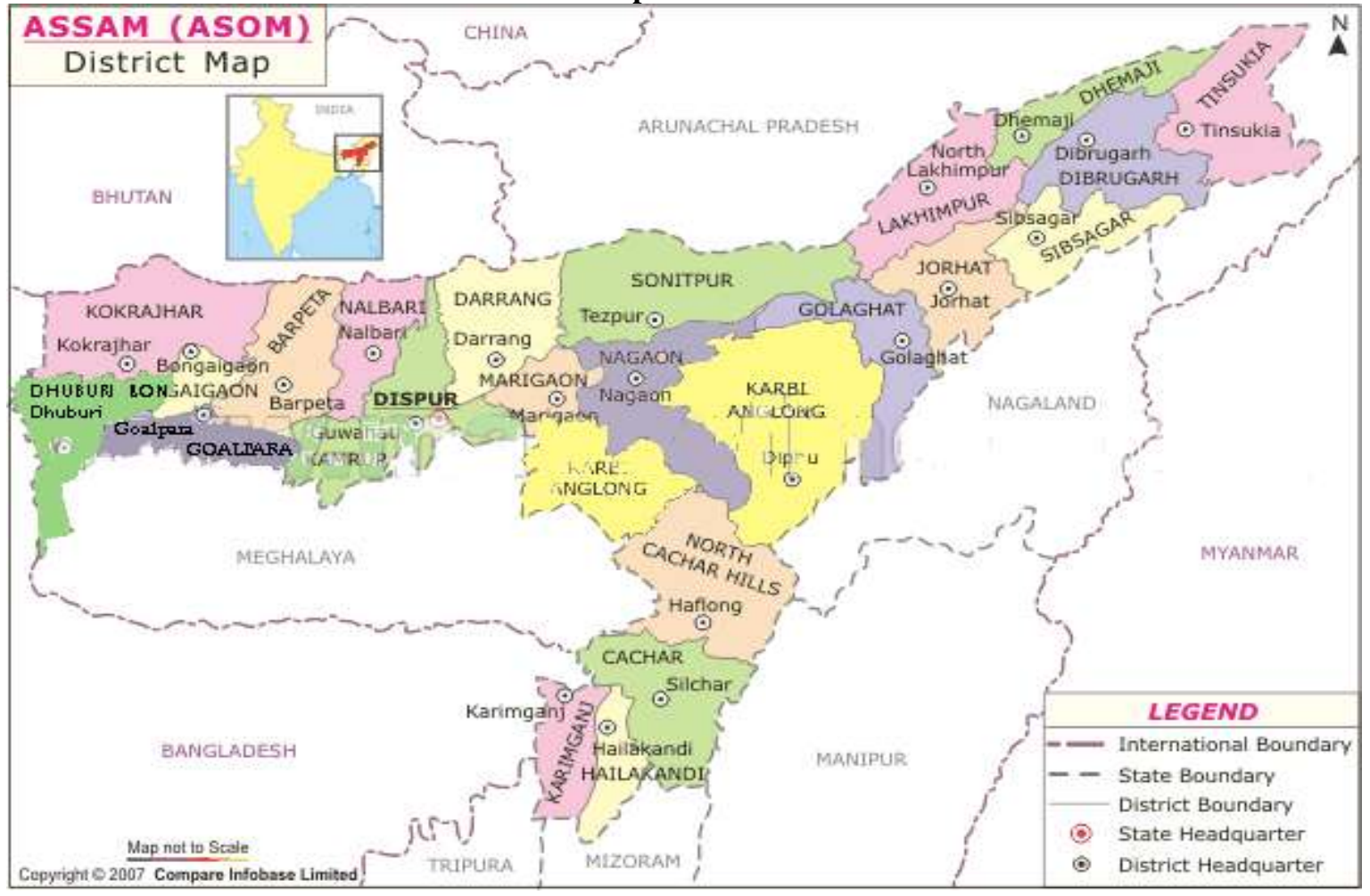




\section{APPENDIX 5}

Map of Cachar District (Geographical)

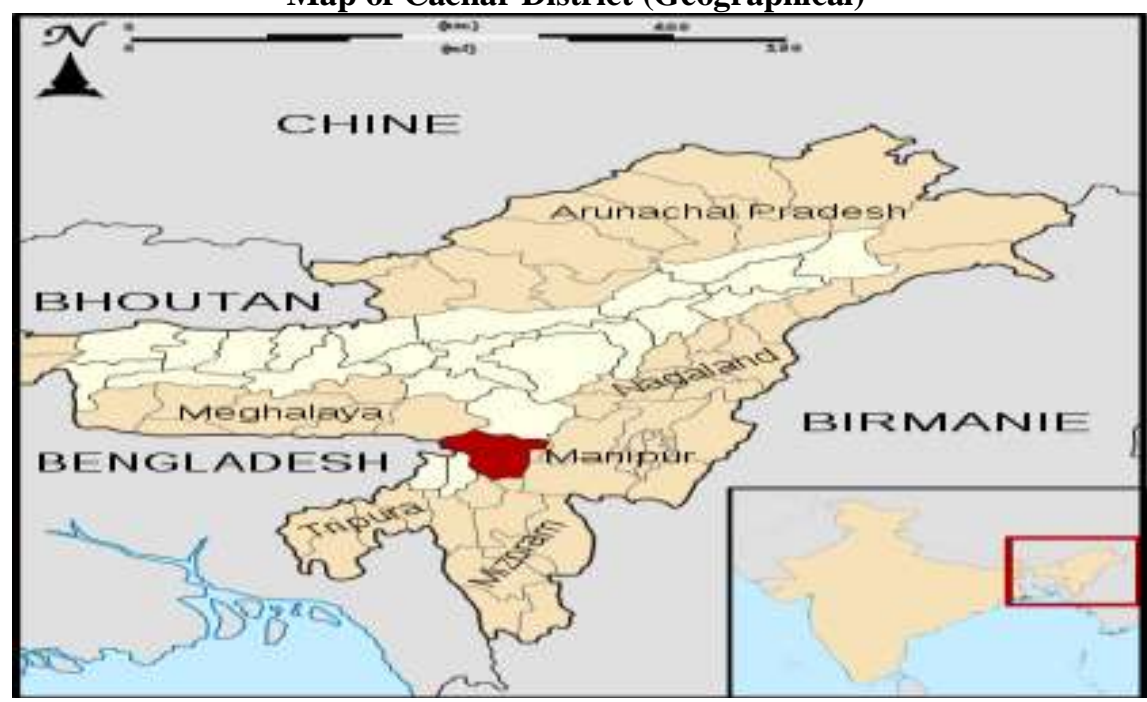

Appendix 6

Location of Silchar town in Cachar District

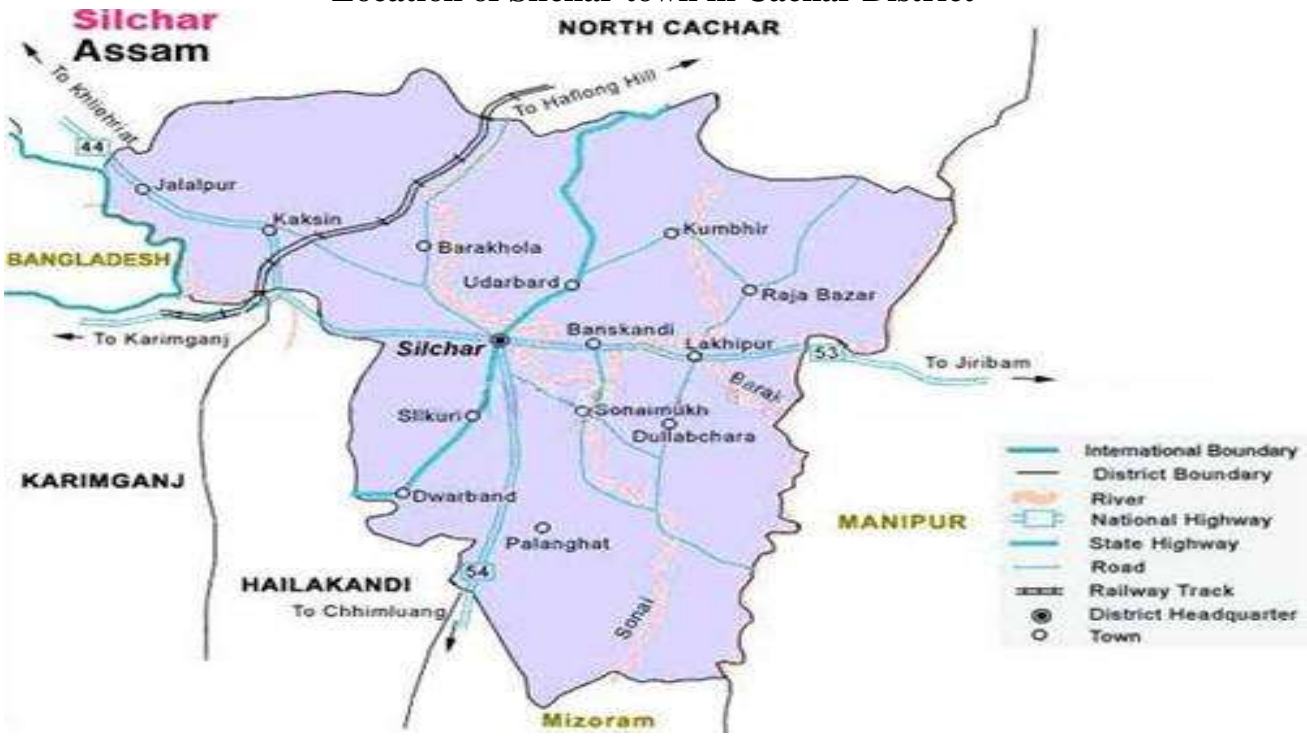

Appendix 7

Map of Silchar Municipal Area

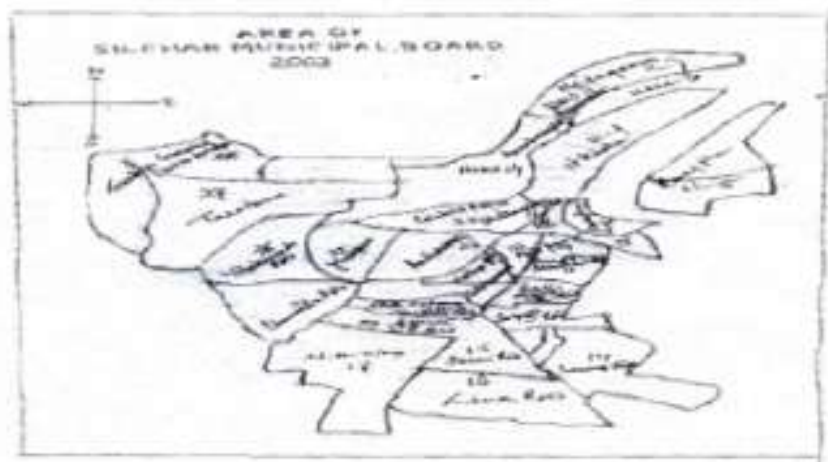

